\title{
ČINNOST DRUŽSTVA ČESKÉHO DIVADLA V OLOMOUCI V LETECH 1920-1925 ${ }^{1}$
}

Olomouc patřila od počátku k městům se silným duchovním a kulturním zázemím. Po staletí tu vedle sebe paralelně fungovala německá a česká kultura, i když soužití nebylo zcela idylické a přinášelo mnoho problémů. Rychlejšímu rozvoji českého divadelnictví po dlouhou dobu bránilo několik skutečností: komunikační problém s německou radnicí, absence vlastního, českého divadelního sálu či přímo budovy i poloamatérský charakter divadelní činnosti. ${ }^{2}$ Postupná změna přicházela s přelomem 19. a 20. století, kdy sílily impulsy vedoucí k vybudování české profesionální scény. Reálné obrysy dostaly v Olomouci, stejně jako v dalších městech českých zemí, ${ }^{3}$ až založením Družstva pro zřízení českého divadla (1907). ${ }^{4}$

\section{Prvotní obtíže Družstva českého divadla v Olomouci}

Nově vzniklé družstvo mělo ve svých stanovách zakotveno provozování divadelní živnosti, zřízení české divadelní scény, vytvoření souboru, zakoupení dekorací a garderoby, zajištění provozovacích práv a dalších náležitostí, jež byly nezbytně nutné $\mathrm{k}$ chodu této instituce. ${ }^{5}$ Členové družstva neskrývali značné ambice a dalekosáhlé plány, jejich realizace však vázla. ${ }^{6}$ Když si roku 1908 vyhlédli

1 S ohledem na soubory tzv. hudebního divadla, zejména s přihlédnutím k záležitostem olomouckého baletu v dané době. Studie vznikla v rámci projektu FPVČ2013/08 na UP v Olomouci.

2 ŠTEFANIDES, Jiří a kolektiv. Kalendárium dějin divadla v Olomouci. Praha: Pražská scéna, 2007, s. 47.

3 Obdobně vzniklo Družstvo českého divadla v Brně (1881), či Spolek Národního divadla v Ostravě (1918) atd.

4 Dále jen družstvo.

5 Olomoucké české divadlo v saisoně 1926-1927. Výroční zpráva Družstva českého divadla v Olomouci za dobu od 1. července 1926 do 30. června 1927. Olomouc: Lidové závody tiskařské a nakladatelské, 1927, s. 3.

6 České divadlo Olomoucké po desíti letech. Přehled práce Družstva českého divadla v Olo- 
trri budovy za Národním domem, na jejichž místě se mělo vystavět nové české divadlo, nebyl výbor schopen překonat potíže způsobené olomouckou německou radnicí a dokonce nezískal ani koncesi na provozování divadla pro další sezonu. V reálu to znamenalo, že české profesionální společnosti, které do Olomouce zavítaly, musely hrát na předměstích. Situace se ještě zhoršila v roce 1910, kdy městská správa uznala družstvo za nevyhovující zákonným předpisům a vyzvala jeho členy, aby se přseskupili v jiný útvar. Vznikl sice spolek, ten ovšem nevyvíjel téměr žádnou činnost. ${ }^{7} \mathrm{~A},[. .$.$] nové obdobi se započíná na sklonku světové války,$ $v$ predvečer našeho národního a státního osvobozeni. " ${ }^{8}$ Před první světovou válkou mělo družstvo dvacet členů a jmění spolku bylo vyčísleno na jeden tisíc sto trricet dva korun. Naopak poválečné stavy členů i financí rychle stoupaly a představy o novém českém divadle opět nabyly reálnějších obrysů. Na podzim roku 1918, přesněji13. listopadu se uskutečnila první poválečná valná hromada, na níž byl předsedou zvolen František Votruba, primář zemské nemocnice. Družstvo si ihned vytyčilo cíl: „Opatřiti našemu českému městu a celému kraji středni a severni Moravy stálé české divadlo v Olomouci a ziskávati finanční základ a stavebni fond pro zbudováni di̊stojné divadelní budovy pro české divadlo v Olomou$c i$." ${ }^{\text {"9 }}$ Podpora českému divadlu šla napříč veřejností a počet členů družstva se již během první sezony 1919/1920 rozrostl na sedm set padesát devět. Jednatelskou zprávu uzavřel výbor pozitivně s tím, že pochopení pro českou divadelní otázku v Olomouci bylo probuzeno a neustále se šírí dál. ${ }^{10}$

\section{Od ambicí k činům}

Družstvo v prvním roce skutečně vyvinulo značné úsilí pro získání nejen nových př́znivců českého divadla, ale i významných osobností, které by podpořili jejich plány. Stejné to bylo i se získáváním finančních prostředků k následné rea-

mouci za léta 1920-1930, Olomouc: Lidové závody tiskařské a nakladatelské, 1930, s. 6. Historicky prvním předsedou družstva se stal primář všeobecné zemské nemocnice dr. Otakar Kose, místopředsedou císařský rada Antonín Balcárek, pokladníkem Josef Dvořák, jednatelem advokát dr. Ferdinand Tomek a správcem budov, které prozatím neexistovaly, dr. František Smrčka. Zakládajících členů ve výboru bylo 19. Dokonce se ředitel divadla východočeských měst František Lacina nabídl, že pomůže založit pro Prostějov, Přerov, Kroměříž, Moravskou Ostravu a speciálně pro Olomouc operní, operetní a činoherní společnost po vzoru východočeské společnosti. Všechny tyto návrhy i nabídky byly zatím předčasné, nebot' jednání i činnost družstva $\mathrm{v}$ průběhu prvního roku ustrnula.

$7 \quad$ Pro Národní divadlo v Olomouci. Pamétni spis divadelních slavností o letnicích 1919. Olomouc: Národní knih a kamenotiskárny Kramář a Procházka, 1919, s. 20-21.

8 Výroční zpráva Družstva českého divadla v Olomouci, za dobu od 13. listopadu 1918 do 29. února 1920, Olomouc: Národní knih a kamenotiskárny Kramář a Procházka, 1920, s. 1.

9 Výroční zpráva Družstva českého divadla v Olomouci, za dobu od 13. listopadu 1918 do 29. února 1920, op. cit., s. 1-2.

10 Majetek družstva ke konci roku 1919 čítal celkem 269246 korun. Výroční zpráva Družstva českého divadla v Olomouci, za dobu od 13. listopadu 1918 do 29. února 1920, op. cit., s. 9. 
lizaci a spuštění provozu. Lze říci, že pro propagaci udělali maximum - od vlastní agitace mezi obyvatelstvem, vojenskou posádkou, přes reklamu až po divadelní slavnosti, jejichž výtěžek měl sloužit jako základ pro stavbu nové divadelní budovy. ${ }^{11}$ Do vlastnictví byl získán také velký pozemek mezi budovou Justičního paláce (dnešního Okresního soudu) a evangelickým kostelem. Počáteční jednání bohužel neměla tak hladký průběh, jak si členové družstva představovali. Protesty ihned vznesla německá menšina, která doporučovala odprodej pozemku za čtyřicet tisíc korun. Městská správa nakonec vyšla vstříc české straně a ještě přislíbila podporu dvě stě padesát tisíc korun pro nadcházející sezonu. Mimo to propůjčila zdarma družstvu budovu Městského divadla na dobu šesti let s platností od května roku 1920, ovšem s podmínkou, že čtyři měsíce z každého roku bude přenecháno divadlo německému spolku. Radnice se dále zavázala poskytovat za měsíční poplatek pět tisíc korun městské hudebníky v počtu dvaceti šesti osob k provozování hudebního divadla, tj. oper, operet a baletů, a to dokonce i při zájezdové činnosti. Za to si však vyhradila právo zasahovat do volby repertoáru a korigovat výši vstupného. ${ }^{12}$

Stav divadelních záležitostí se družstvu jevil v danou chvíli jako upokojivý, navíc dosud trvající poválečná euforie sebou nesla i vysoké cíle a vzletné myšlenky, „aby v tomto novém období českého divadelnictví v Olomouci za správy družstva a za pomoci a součinnosti města a celé české veřejnosti, otázky a záležitosti divadelní byly povzneseny na výši odpovídajici duchu a požadavküm doby, jak po stránce umělecké, tak i svou prosperitou, aby město Olomouc stalo se $i$ v divadelnictví významným a hledaným ohniskem nejen svého okolí, nýbrž i celého velkého kraje." ${ }^{13}$ Tomu odpovídaly také plány na stavbu nové divadelní budovy, jejíž proporce by byly i na dnešní dobu značně naddimenzované. Hlediště mělo čítat dva tisíce pět set míst, z toho třicet loží po pěti osobách, dále tisíc osm set padesát sedadel a počítalo se i s pěti sty místy na stání. Jevištní prostor by na šiřku dosahoval dvacet dva metrů, hloubky sedmnáct metrů a proscénium by zabíralo jedenáct metrů. Předseda stavebního odboru, doktor František Smrčka dále plány upřesnil: „Mimo to maji býti při jevišti př́pravné scény, šatny sólistů i ostatnich účinkujicich, mistnosti pro ředitele a režiséra a kapelnika, hovorna, koupelny a sprchy atd. Má býti pamatováno na sín pro zkoušky hudební, sborové, zřizeno zvláštni zkušebni jeviště, skladiště kostýmů aj. potřeb a príručnich

11 Divadelní slavnosti probíhaly ve dnech 6.-8. záŕí roku 1919, organizačně je zajišt'ovaly české spolky a výtěžek šel ve prospěch Družstva českého divadla v Olomouci. Slavnosti zahájil promenádní koncert ve Smetanových sadech a večer následovala Maryša bratř́i Mrštíků v Národním domě. V městském divadle uvedl pěvecko-hudební spolek Žerotín Kovařovicovy Psohlavce, v hlavních rolích se představili Emil Olšovský a Jetty Kurzová, Josef Schwarz či Helena Monczaková. V neděli se konal krojovaný průvod a se svým proslovem vystoupil režisér a dramatik Karel Kvapil. V pondělí se uskutečnilo představení Jiráskovy Lucerny a Kovařovicových Psohlavcü. ŠTEFANIDES, op. cit., s. 77-78.

12 Výroční zpráva Družstva českého divadla v Olomouci, za dobu od 13. listopadu 1918 do 29. února 1920, op. cit., s. 5.

13 Výroční zpráva Družstva českého divadla v Olomouci, za dobu od 13. listopadu 1918 do 29. února 1920, op. cit., s. 5. 
dekorací. Orchestr má pojmouti až sto hudebniků. Místnosti pro policii, hasiče, lékaře, správu divadla, účtárnu, pokladnu, knihovnu atd. od vnitřku divadla odděleně maji býti umistěny obchody s lahůdkami, cukrovím, květinami, novinami, holič atd. " ${ }^{14}$ Dalo by se říci, že takové plány olomouckého družstva téměř odpovídaly pozdější stavbě Janáčkova divadla v Brně. Mimo to, počítaly s kompletním zázemím a službami nejen pro účinkující a personál, ale také pro diváka. K vypracování návrhu podmínek při vypsání soutěže pro výstavbu nového českého divadla ochotně připojil své poznámky a rady architekt Gustav Schmoranz, ředitel Národního divadla v Praze Jaroslav Kvapil, šéf opery Národního divadla Karel Kovařovic, známý architekt Jaroslav Kotěra a architekt František Skopalík z Vídně. Termín odevzdání návrhů byl dvakrát posunut, výsledně až na duben roku 1921. První cena byla udělena architektu Pavlu Janákovi, ke stavbě divadla však nikdy nedošlo. ${ }^{15}$

Souběžně se od května roku 1919 začalo mluvit o možnosti převodu dosavadního německého Městského divadla do českých rukou. ${ }^{16}$ „V té chvíli bylo i německému obyvatelstvu jasné, že je po vzniku československého státu jejich výlučné vlastnictví nejdi̊ležitějši kulturni instituce ve městě ohroženo. Proces prevzetí německého divadla do české správy byl postupný. "17 $\mathrm{Na}$ české straně začala na jaře roku 1920 jednání o volbě vhodného kandidáta na funkci ředitele, nebot' družstvo odmítlo vést divadlo ve vlastní režii. Adeptů bylo celkem šest ${ }^{18}$ a po složitých jednáních byl vybrán Jaroslav Stuka-Wilkonský, s nímž družstvo uzavřelo smlouvu na jeden rok. ${ }^{19}$ Ale až do divadelních prázdnin 1920 mělo Městské divadlo německého ředitele, jímž byl Robert Schliesmann-Brandt. ${ }^{20}$ Německá scéna udržovala omezený provoz i nadále do sezony 1922/1923, poté se administrativně stala součástí brněnského divadla $\mathrm{v}$ režii olomouckého německého divadelního spolku.

14 Výroční zpráva Družstva českého divadla v Olomouci, za dobu od 13. listopadu 1918 do 29. února 1920, op. cit., s. 8.

15 ŠTEFANIDES, op. cit., s. 82.

16 KŘUPKOVÁ, Lenka. Die Dämmerung des Olmützer deutschen Theaters. Musicologica Brunensia 2010, roč. 45, č. 1-2, s. 151.

17 KŘUPKOVÁ, Lenka. Německá operní scéna v Olomouci II. 1878-1920. Olomouc: Univerzita Palackého v Olomouci 2012, s. 281.

18 Bedřich Jeřábek, Vl. Marek, Ad. Marka, František Trnka, Josef Burda a Jaroslav Stuka-Wilkonský. České divadlo Olomoucké po desíti letech, op. cit., s. 22.

19 Přesto v sezoně, jako šéf operního a operetního souboru, uvedl Smetanovu Hubičku, Prodanou nevěstu, Dalibora, Massenetova Werthera, d'Albertovu Nižinu, Bizetovu Carmen, Pucciniho Madame Butterfly či Kovařovicovy Psohlavce; z operet Hervého Mamzelle Nitouche, Straussova Netopýra nebo Nedbalovu Polskou krev. HUDEC, Vladimír. Kalendárium opery a operety. In Acta Universitatis Palackianae Olomucensis. Musicologica Olomucensia. Musicologica Olomucensia 2006, č. 8, s. 154.

20 VIČAR, Jan a kolektiv. Hudba v Olomouci 1945-2013. Olomouc: Univerzita Palackého v Olomouci 2014, s. 22. 
V tomto období zabezpečovaly představení hudebního divadla (opery, operety a baletu) české spolky, především největší z nich, Žerotín. Mimo to do Olomouce zajížděly divadelní soubory a společnosti. Takovým př́ípadem bylo i taneční představení Štědrovečerni sen na počátku roku 1920, které vzešlo ze spolupráce pěvecko-hudebního spolku Žerotín s Angerovým baletem a s baletním souborem vedeným Annou Marií Psotovou. ${ }^{21}$ Soubor byl po velkém úspěchu pozván do Olomouce ještě jednou v květnu téhož roku, aby uvedli balet Léo Délibese Coppélia. Všechna představení dirigoval nově zvolený ředitel olomouckého českého divadla Jaroslav Stuka-Wilkonský, jenž tímto pomyslně převzal divadelní štafetu. ${ }^{22}$

\section{První sezona českého profesionálního divadla v Olomouci}

Budova městského divadla byla předána do rukou družstva $\mathrm{v}$ den slavnostního zahájení 1. září 1920, kdy na scéně vystoupila Amalie Bobková v roli Libuše ve stejnojmenné opeře Bedřicha Smetany. ${ }^{23}$ První oficiální sezona trvala pouze do 28. února 1921 a během ní se postupně konsolidovaly všechny soubory. V rámci hudebního divadla bychom mohli hovořit spíše o jednom velkém ansámblu, protože práce baletního souboru byla úzce spojena s operou a operetou. „Jelikož prevážná část úkolů navazovala na repertoár opery a operety, omezovala se samostatná umělecká činnost souboru zpravidla na jediný celovečerní balet v roce." ${ }^{24}$ Poprvé se baletní soubor českého profesionálního divadla v Olomouci představil divákům v operetě Polská krev dne 3. zář́i 1920, na choreografii všech tanečních výstupů se podílel nově zvolený baletní mistr Václav Fabián. ${ }^{25}$

Přestože sezona 1920/1921 byla krátká, pouze šestiměsiční a dle názoru členů družstva finančně zabezpečená, byl řediteli Wilkonskému vytýkán zcela laxní př́stup k zájezdové činnosti divadla. V dubnu roku 1921 oznámil sám Wilkonský výboru družstva, že již nemá finanční prostředky a rozpustí soubory. Družstvo si bylo vědomo, že pokud by divadelní sezóna skončila takto, poškodilo by to nejen jméno jednotlivých členů výboru, ale i všechny snahy o vybudování kvalitní

21 Matka známého brněnského tanečníka a choreografa Iva Váňi Psoty, která měla v Přerově baletní školu a taneční soubor.

ŠTEFANIDES, op. cit, s. 79.

23 ŠTEFANIDES, op. cit, s. 80.

24 KABELÁČ, Vojtěch - VÍTEK, Svetozar (red.): Balet. Olomoucké divadlo v desetiletí 1945 1955, Olomouc, 1955, s. 29.

25 Václav Fabián (1880-1955) byl nejprve tanečníkem v Národním divadle v Praze (19031906), poté baletním mistrem v pražských předměstských scénách (např. Aréna na Smíchově). Po olomouckém angažmá působil jako sólista a baletní mistr ve Vinohradské zpěvohře, kde nastudoval množství tanečních čísel do operetních představení a her se zpěvy, za všechny zmiňme např. Kalmánovu Bajadéru (1923), Offenbachova Orfea v podsvětí (1925). Společně se svou manželkou, primabalerínou Karlou Fabiánovou, účinkovali pod názvem Duo Fabiani. Poté v letech 1928-1934 zastával Václav Fabián funkci baletního mistra v Tylově divadle v Nuslích. HOLEŇOVÁ, Jana a kol. Český taneční slovnik: Tanec, balet, pantomima, Praha: Divadelní ústav, 2001, s. 68. 
české divadelní scény. ${ }^{26} \mathrm{Z}$ toho důvodu se snažilo zbývající měsíce provozu zabezpečit a umělcům vyplatit gáže. Ze stejné př́ičiny došlo i k reorganizaci souborů a byl zvolen nový ředitel. S platností od 1. záŕí 1921 se jím stal Antonín Drašar, který setrval $\mathrm{v}$ čele divadla plných deset let a po celou dobu svého působení usiloval o jeho ekonomickou stabilitu i zvyšování umělecké úrovně. Díky jeho neúnavné aktivitě narůstala zájezdová činnost nejen po Moravských a Českých městech, ale snažil se expandovat i do zahraničí. ${ }^{27}$ Opakovaně v této době podnikl soubor olomoucké opery zájezdy do Vídně či Krakova. ${ }^{28}$

\section{Období stabilizace divadelního provozu}

Před druhou sezonou 1921/1922 vyvstalo družstvu opět několik palčivých otázek finančních i administrativních. Znovu se rozpoutala také diskuze o délce sezony a vymezení prostoru pro německé divadlo. Družstvo si totiž na městské radě vymohlo nikoli šesti, ale osmiměsíční divadelní sezonu, s čímž německá obec nesouhlasila. Recipročně se však zavázalo na sebe vzít veškeré výlohy, které tímto krokem městu vzniknou. To bylo poměrně odvážné, protože se fakticky vzdalo městské subvence a ještě zvýšilo poplatek za propůjčení městské hudby z pěti na osm tisíc. Ale i tak se neustále řešila otázka převzetí Městské hudby pod správu samotného družstva, s čímž nesouhlasili ani jeho členové ani samotní hudebníci. Problém nastal také se zabezpečením umělců v období od dubna do srpna, kdy divadlo v Olomouci nehrálo. Naštěstí se povedlo členům družstva získat subvenci zemského výboru v Brně a byly domluveny letní stagiony zpěvohry v jiných městech, např. Prostějově, Přerově, Pardubicích či Jihlavě. ${ }^{29} \mathrm{I}$ tak zůstalo $\mathrm{k}$ vyřešení na další sezonu mnoho provozních problémů, od doplnění operního, operetního a baletního souboru až po zajištění kancelářských místností a bytů zhruba pro osmdesát osob.

Také ve vlastních uměleckých záležitostech bylo družstvo velmi aktivní. Soustředilo se na uvádění českých autorů a počet premiér jednotlivých souborů byl na dnešní dobu neskutečně vysoký (opera dvacet dva a činohra třicet pět za zkrácenou sezonu). Balet v této sezoně uvedl svou skutečně první premiéru (19. listopadu 1921), když nastudoval dílo Josefa Bayera Královna loutek v jednom večeru spolu s taneční koláží Zpěvy noci na hudbu Frederika Chopina. Choreografii vytvořil olomoucký baletní mistr Václav Fabián, režijně se na inscenaci podílel Vladimír Nechyba,

26 Na Wilkonského podalo družstvo i žalobu, ale jinak se snažilo co nejrychleji aféru zlikvidovat, aby divadlo mohlo fungovat nerušeně dále. Výroční zpráva Družstva českého divadla v Olomouci za dobu od 1. dubna 1921 do 15. března 1922. Olomouc: Národní knih a kamenotiskárny Kramáŕ a Procházka, 1922, s. 4-5.

27 ŠTEFANIDES, op. cit, s. 83.

28 KUČEROVÁ, Alice. Zájezdy Olomoucké opery do Vídně - rok 1924. In Hudba v Olomouci a na střední Moravě III 2009, s. 123-129.

29 Mezi další patřily výlohy na lékařskou péči, či polovina výdajů na opravu fasády divadla. $V y$ roční zpráva Družstva českého divadla v Olomouci za dobu od 1. dubna 1921 do 15. března 1922, op. cit., s. 4-5. 
kterého mohli diváci spatřit i v sólových tanečních výstupech. ${ }^{30}$ Až do roku 1925 to byla jediná baletní premiéra, ${ }^{31}$ důvodů bylo hned několik: tanečníci se podíleli na všech operních i operetních představeních, kromě toho, po celá dvacátá léta docházelo k poměrně rychlému stř́ídání ve vedení baletu. Nejednalo se ještě o šéfa souboru, pouze o baletního mistra, jenž měl na starosti choreografické zpracování tanečních výstupů v operních a operetních představeních, navíc byl sám i sólovým tanečníkem. Soubor sestával z jednoho až dvou sólistů, primabaleríny a prŕípadně další sólistky. Zbytek ansámblu tvořily tzv. balet girls neboli baletní sbor, který byl složen pouze $\mathrm{z}$ tanečnic, jejich počet se pohyboval okolo deseti. ${ }^{32}$ Mimo to se do určitých inscenací najímaly elévky. ${ }^{33} \mathrm{~V}$ některých sezónách dokonce $\mathrm{v}$ ročenkách figuruje pouze několik tanečníků ${ }^{34}$ a sbor nebyl vưbec zveřejněn, zřejmě jím $\mathrm{v}$ rámci úsporných opatření divadlo ani nedisponovalo.

Díky vysokému počtu premiér v sezoně věnovalo družstvo velkou pozornost tvorbě systému předplatného. Snahou bylo samozřejmě zvýšení návštěvnosti, ale i výchova stálých abonentů, což mělo přinést určitou finanční jistotu. Během druhé sezony získalo divadlo z abonomá celkem třicet pět tisíc korun, které rozhodně nebyly v rozpočtu zanedbatelnou částkou..$^{35}$ Divák na oplátku získal třicet představení $\mathrm{v}$ rámci předplatného $\mathrm{s}$ jistým podílem operních, operetních, činoherních a baletních inscenací dle dramaturgického plánu a možností jednotlivých souborů. Čelní představitelé družstva také rychle pochopili, že je třeba sezonu ozvláštnit hostování významných umělců a těles, $\mathrm{z}$ tohoto důvodů se $\mathrm{v}$ rámci sezony v titulních rolích objevili Otakar Mařák, Mary Cavanová, Ludmila Prokopová nebo s vlastní inscenací dorazil do Olomouce Moskevský balet. ${ }^{36}$

V následujících letech přibyly družstvu kromě finančních problémů i potíže $\mathrm{s}$ konkurencí v podobě filmového průmyslu. Divadla, to olomoucké nevyjímaje,

30 Vladimír Nechyba (1897-1955) tanečník, baletní mistr a člen olomouckého divadla v letech 1921-1953. Nechyba nepatř̌il mezi úzce zaměřené umělce, zprvu se prosadil jako tanečník, poté coby baletní mistr, od roku 1928 i jako choreograf, zpěvák, herec, výtvarník a režisér. Po druhé světové válce se stal šéfem operety. V sólových tanečních rolích hostoval také v divadle v Brně. HOLEŇOVÁ, op. cit., s 215.

31 DRLÍK, Vojen a kolektiv. Moravské divadlo Olomouc 1920-2000, Olomouc: Moravské divadlo Olomouc 2000, s. 73.

32 Výroční zpráva družstva českého divadla v Olomouci za roky 1930/1931 a 1931/1932. Olomouc: Linografia, 1932, s. 45.

33 DRLÍK, op. cit., s. 73.

34 Jednalo se o léta 1922 až 1926, kdy soubor tvořili manželé Anna a Ladislav Nechybovi. Olomoucké české divadlo v saisoně 1923/1924. Olomouc: Družstvo českého divadla, 1924, s. 18. Též: Olomoucké české divadlo v saisoně 1924/1925. Olomouc: Lidová tiskárna, 1925, s. 28.

35 Celkový zisk divadla za rok 1921 činil 1122197 korun.

36 Výroční zpráva Družstva českého divadla v Olomouci za dobu od 1. dubna 1921 do 15. brezna 1922, op. cit., s. 11-13. Družstvo vydávalo i periodikum s názvem Meziaktí, kde se nacházely př́spěvky vážící se jak přímo k olomoucké scéně, historii a vzniku významných děl českého i světového repertoáru, tak novinky a události celorepublikového významu. Sloužit měl v podstatě $\mathrm{k}$ „osvětě“ a další výchově diváka. 
se snažila vyrovnat s novou situací přitažlivým repertoárem, konkrétně v rámci hudebního divadla se těšila velké oblibě operetní a revuální představení. ${ }^{37}$ Nadále zůstávalo mnoho nevyř̌šených záležitostí, i přesto, že po třetí sezoně (1922/1923) již považovalo družstvo české profesionální divadlo v Olomouci za stabilizované. $\mathrm{K}$ nejpalčivějším z nich patřila rekonstrukce stávající divadelní budovy, kdy z mnoha úkolů se podařilo osobním přispěním generála Kroupy pořídit pouze novou oponu za třicet tři tisíc korun. K rozšíření orchestřiště bohužel nedošlo, ani k dostavbě skladů, rekonstrukci provazišst', či nákupu reflektorů. Dokonce se v polovině sezóny natolik zhoršila finanční situace, že byli členové družstva nuceni snižit gáže o čtyři až deset procent. To ovšem přineslo vleklé spory zejména se členy orchestru a techniky. Sezona končila 30 . května a výbor okamžitě domluvil letní stagionu olomoucké opery v Praze a v Karlových Varech. Tam se nacházelo množství lázeňských hostů, tedy i možných návštěvníků představení. Dle dochovaných zdrojů byly obě tyto letní stagiony úspěšné, což znamenalo především zvýšení umělecké prestiže olomouckého divadla. Přestože i po finanční stránce dopadlo hostování velmi dobře, bylo nutné ještě sedmdesát devět tisíc na operní soubor doplatit. Výbor družstva v této sezoně definitivně pochopil, že divadlo nemůže být finančně soběstačné a že město ani kraj nejsou schopni udržet subvence v takové výši, aby byla zaručena naprostá finanční stabilita. ${ }^{38}$ Nezbývalo než dále bojovat $\mathrm{a}$ apelovat na samotné diváky $\mathrm{i}$ členy družstva $\mathrm{k}$ finanční podpoře a dobré vůli. ${ }^{39}$

\section{Přelomové sezony}

Ani v nadcházející sezoně 1923/1924 si družstvo nemohlo stěžovat na nedostatek zátěžových situací. Samo hodnotilo všechny dosavadní léta jako boj o existenci jak v umělecké, tak ekonomické sfére. Finanční stránka př́mo souvisela s uměleckou úrovní divadla. Pro správné fungování zázemí bylo nutné disponovat vlastním zařízením, proto družstvo odkoupilo celý fundus, garderobu a zejména hudební archiv od soukromé osoby za dvě stě padesát tisíc korun, které se zavázalo splatit do dvou let.

Kromě jiného kulminovala vlna sporů s členy jednotlivých uměleckých souborů o zájezdové honoráře. ${ }^{40} \mathrm{~V}$ první polovině roku 1923 došlo ke snížení zájezdových honorářu o padesát procent, což se setkalo $\mathrm{s}$ velkou nevolí zejména členů ansámblů hudebního divadla. ${ }^{41}$ Situace se znovu vyhrotila v roce 1924, kdy

37 V Olomouci nadměrná obliba operety přetrvávala u obecenstva po celé 20. století.

38 V průběhu roku 1922 začal narůstat provozní schodek, který v dubnu roku 1923 dosáhl téměř milionu korun.

39 Výroční zpráva družstva českého divadla v Olomouci za dobu od ledna 1922 do června 1923, op. cit., s. 4-8.

40 Olomoucké české divadlo v sezoně 1923/24, op. cit., s. 8.

41 Výroční zpráva Družstva českého divadla v Olomouci za dobu od ledna 1922 do června 1923, op. cit., s. 6. 
olomoucká opera podnikla zájezd do Vídně. Nakonec došlo ke konsensu s umělci a hostování se setkalo s kladnou odezvou na všech třicet sedm představení, zejména Smetanovského repertoáru. I přes tyto problémy bylo divadlo hrdé na svou bohatou zájezdovou činnost a zejména na fakt, že finanční situaci dále nezhoršilo. Se značnou námahou, z velké části díky obchodním schopnostem ředitele Antonína Drašara a s malými dotacemi města, země i státu, se podařilo udržet schodek $\mathrm{v}$ rozpočtu kolem jednoho milionu korun.

Skutečně přelomová byla až sezona 1924/1925, kdy došlo ke stabilizaci vztahů s městem a divadlo začalo fungovat jako jednotná organizace. Samožrejmě přetrvávaly finanční, administrativní i umělecké problémy, ale těm se u tak velké instituce s tak vysokým počtem zaměstnanců nelze nikdy zcela vyhnout. Nejdůležitějším krokem družstva $\mathrm{v}$ této sezoně byl podpis nové smlouvy s městem, upravující jejich vztahy, nejen na bázi ekonomické, ale i umělecké. $\mathrm{V}$ rámci těchto ujednání došlo totiž $\mathrm{k}$ převzetí dosavadního městského orchestru do správy divadla. Mimo to byly po dlouhých úvahách odprodány pozemky pro nové velké divadlo a družstvo konečně přikročilo k opravě a dostavbě stávající budovy. Finančně nejnáročnější operací se stala celková rekonstrukce jeviště a stavba skladiště kulis. Při velkém počtu premiér, které divadlo za sezonu uvádělo, narůstal počet kulis nezadržitelně tak, že je již nebylo kde uskladnit. ${ }^{42}$ Aby družstvo finančně vyvážilo tyto nákladné operace a zároveň se vyrovnalo s kinematografickým průmyslem, přistoupilo $\mathrm{k}$ takzvanému boji formou útoku. Zakoupilo kinematografickou koncesi i kino Edison $\mathrm{s}$ budovou, $\mathrm{v}$ níž sídlilo, čímž získalo pod kontrolu velkou část kulturního dění ve městě. „Voditkem při všech těchto akcich byla predsednictvu a výboru družstva českého divadla neochvějná a cilevědomá snaha, pozvolným, ale bezpečným tempem vybudovati našemu velkému uměleckému a kulturnímu podniku olomouckému co nejpevnějši a co nejsolidnějši basi hmotnou. Tento daleký a vysoký cíl musíme sledovati i nadále. Dnes jsme pouze na nejprvnějším začátku své klopotné a obtižné cesty. “43 Velký podíl na konsolidaci poměrů v divadle měl i ředitel Antonín Drašar, jehož zásluhy byly mnohokrát vyzdvihovány výborem družstva.

Umělecká úroveň souborů stoupala, i když se nikdy zcela nezbavila závislosti na personálním i provozním stavu olomouckého divadla. Vše bylo úměrné možnostem a finančním prostředkům družstva, které v prvních pěti letech dokázalo poměry, sice s velkými těžkostmi, konsolidovat. Členové výboru záhy velmi dobře pochopili, že správa kulturní instituce je nikdy nekončící boj o její finanční i umělecké zajištění. Díky jejich houževnatosti a nesmírné vytrvalosti můžeme od poloviny dvacátých let chápat provoz českého divadla v Olomouci jako stabilizovaný a fungující v dnešním slova smyslu.

Alice Ondrejková (alice.ondrejkova@upol.cz), Katedra muzikologie, Filozofická fakulta, Univerzita Palackého, Olomouc, CZ.

42 Výroční správa Družstva českého divadla v Olomouci za dobu od 1. července 1924 do 30. června 1925. Olomouc: Lidová tiskárna, 1925, s. 5-7.

43 Výroční správa Družstva českého divadla v Olomouci za dobu od 1. července 1924 do 30. června 1925, op. cit., s. 5. 


\section{ABSTRACT \\ THE ACTIVITIES OF THE ASSOCIATION OF CZECH THEATER IN OLOMOUC IN THE YEARS 1920-1925}

In Olomouc, as in other cities in our country, was founded the Association of Czech theater in the early 20th century. The main task of the Association was the establishment of a czech professional scene in Olomouc. This task was fullfilled after the founding of the Czechoslovak republic, in 1920, when a german theater came under czech administration. The first five years have been established ensembles, including the ballet, and the theatre made new repertoire. The Association solved the financial and administrative problems of the theater. In the mid-twenties of the 20th century the Association signed a new contract with the Town Hall in Olomuc and the theater has worked with all the ensembles and its own facilities.

\section{Key words}

Olomouc, theatre, Association of the Czech theatre, opera, ballet

\section{Bibliography}

České divadlo Olomoucké po desíti letech. Přehled práce Družstva českého divadla v Olomouci za léta 1920-1930. Olomouc: Lidové závody tiskařské a nakladatelské, 1930.

DRLÍK, Vojen a kolektiv. Moravské divadlo Olomouc 1920-2000, Olomouc: Moravské divadlo Olomouc, 2000.

HOLEŇOVÁ, Jana a kol. Český taneční slovnik: Tanec, balet, pantomima, Praha: Divadelní ústav, 2001. HUDEC, Vladimír. Kalendárium opery a operety. In Acta Universitatis Palackianae Olomucensis. Musicologica Olomucensia. Musicologica Olomucensia 2006, č. 8, s. 153-231.

KŘUPKOVÁ, Lenka. Die Dämmerung des Olmützer deutschen Theaters. Musicologica Brunensia, 2010, roč. 45, č. 1-2, s. 149-162.

KŘUPKOVÁ, Lenka. Německá operní scéna v Olomouci II. 1878-1920. Olomouc: Univerzita Palackého v Olomouci, 2012.

KUČEROVÁ, Alice. Zájezdy Olomoucké opery do Vídně - rok 1924. In Hudba v Olomouci a na střední Moravě III 2009, s. 123-129.

Olomoucké české divadlo v saisoně 1923/1924. Olomouc: Družstvo českého divadla, 1924.

Olomoucké české divadlo v saisoně 1924/1925. Olomouc: Lidová tiskárna, 1925.

Olomoucké české divadlo v saisoně 1926-1927. Výroční zpráva Družstva českého divadla v Olomouci za dobu od 1. července 1926 do 30. června 1927. Olomouc: Lidové závody tiskařské a nakladatelské, 1927.

Pro Národni divadlo v Olomouci. Pamětni spis divadelních slavností o letnicích 1919. Olomouc: Národní knih a kamenotiskárny Kramáŕ a Procházka, 1919.

ŠTEFANIDES, Jiří a kolektiv. Kalendárium dějin divadla v Olomouci. Praha: Pražská scéna, 2007.

VIČAR, Jan a kolektiv. Hudba v Olomouci 1945-2013. Olomouc: Univerzita Palackého v Olomouci, 2014.

Výroční správa Družstva českého divadla v Olomouci za dobu od 1. července 1924 do 30 . června 1925. Olomouc: Lidová tiskárna, 1925.

Výroční zpráva družstva českého divadla v Olomouci za roky 1930/1931 a 1931/1932. Olomouc: Linografia, 1932.

Výroční zpráva Družstva českého divadla v Olomouci za dobu od 1. dubna 1921 do 15. března 1922. Olomouc: Národní knih a kamenotiskárny Kramář a Procházka, 1922.

Výroční zpráva Družstva českého divadla v Olomouci, za dobu od 13. listopadu 1918 do 29. února 1920. Olomouc: Národní knih a kamenotiskárny Kramáŕ a Procházka, 1920. 